\title{
Effect of a GnRH analogue (peforelin) on the litter performance of gilts and sows
}

\author{
Ellen de Jong ${ }^{1,5^{*}}$ D, Jan Jourquin ${ }^{2}$, Johannes Kauffold ${ }^{3}$, Steven Sarrazin ${ }^{4}$, Jeroen Dewulf ${ }^{4}$ and Dominiek Maes ${ }^{1}$
}

\begin{abstract}
Background: Maintaining optimal reproductive and litter performance is essential for meeting economic targets in commercial pig production. Treatment with exogenous gonadotropins in sows after weaning or in gilts after altrenogest treatment has been used to stimulate follicular development leading to more piglets born and eventually higher birth weights. The effect of peforelin on litter performance was investigated in 212 gilts, primiand pluriparous sows in three herds. Animals were randomly allocated to three treatments $24 \mathrm{~h}$ after weaning: peforelin (P group), eCG (E group), and physiological saline solution (C group). Numbers of total, liveborn and stillborn piglets and mortality rate during lactation were recorded. Birth weights and coefficient of variation in weights within litter were assessed. All parameters were compared among treatments.

Results: Over all parities, no difference was found among treatments in litter size nor mortality rate, but birth weights were significantly lower in the E group. Stillbirth numbers in pluriparous sows were 2.2, 0.9 and 1.4 for P, E and $C$ groups, respectively $(p=0.04)$. Piglets in the $\mathrm{P}$ group had significantly higher live born birth weights in gilts, compared to the $E$ group $(1.36,1.26,1.32 \mathrm{~kg}(p<0.02)$ for $P, E$ and $C$ group, respectively). No significant differences were found for the other investigated parameters.
\end{abstract}

Conclusions: Peforelin treatment showed no improvement of litter performance compared to no treatment.

Keywords: Sows, Gonadotropins, Peforelin, Prolificacy, Birth weight

\section{Background}

Maintaining optimal reproductive and litter performance is essential for meeting economic targets in commercial pig production. Treatment with exogenous gonadotropins in sows after weaning or in gilts after altrenogest treatment has been used to stimulate follicular development [1-3]. Follicular stimulation could lead to a better quality of the oocytes and to better embryo viability [4-6], subsequently leading to a higher number of piglets born [7] and eventually higher birth weights [8].

The release of luteinizing hormone (LH) and, to a lesser extent, follicle-stimulating hormone (FSH) from the pituitary gland is governed by the hypothalamic gonadotropin-releasing hormone $(\mathrm{GnRH})$ [1, 9-11]. $\mathrm{GnRH}$ is therefore a key regulator of the growth,

\footnotetext{
* Correspondence: de.jong.ellen@gmail.com

${ }^{1}$ Department of Reproduction Obstetrics and Herd Health, Unit Porcine Health Management, Faculty of Veterinary Medicine, University of Ghent, Salisburylaan 133, B-9820 Merelbeke, Belgium

${ }^{5}$ Present address: Flemish Animal Health Service (Dierengezondheidszorg

Vlaanderen), Industrielaan 29, B-8820 Torhout, Belgium

Full list of author information is available at the end of the article
}

maturation, and ultimately, the ovulation of follicles. While LH secretion is only dependent on GnRH, FSH is also regulated by other peptides, such as gonadal activins, inhibins and follistatins [11-13]. Twenty years ago, Sower et al. (1993) demonstrated for the first time that there is another selective FSH-releasing factor produced by the hypothalamus in fish, more specifically in the lamprey, Petromyzon marinus (lamprey GnRH-III, l-GnRH-III) [14]. Products, which have l-GnRH-III (peforelin) as the active substance, are marketed for the induction of estrus in sows after weaning and in sexually mature gilts after progestagen therapy. Different studies conducted in Germany and Belgium have confirmed that treatment with peforelin has positive effects on estrus induction in gilts and sows [15-17].

Peforelin could positively influence the oocyte quality, ovulation rate, embryonic survival and litter weight. This positive influence on embryonic survival and litter weight was suggested by Jourquin and Goossens (2011) and Vangroenweghe et al. (2013) in litters from peforelin treated sows $[18,19]$. The mortality rate of litters born 
to peforelin treated sows was significantly lower (14 versus $17 \%$ ) and the birth weight was significantly higher (average of 1.24 versus $1.20 \mathrm{~kg}$ ) than in litters from untreated control sows. However, no comparison was made with another gonadotropin-like product and no data were available on the homogeneity of the litters.

The purpose of the study reported herein was to investigate the effect of peforelin on subsequent litter performance in gilts after altrenogest treatment and in post-weaning sows in Belgian sow herds. The performance of the peforelin treated animals was compared to that of a pregnant mare serum gonadotropin (eCG) treated group and a saline treated control group.

\section{Methods}

The study was conducted between January 2010 and May 2011.

\section{Study animals and management practices}

This study was part of a larger study, of which the main objective was to demonstrate differences in estrus rate between the treatment groups [17]. Statistical sample size calculations were performed in relation to this main objective. Of a total of 1945 gilts and sows housed in three sow herds, 262 breeding animals were randomly selected. In Table 1, more detailed information on the farms is presented. The animals were stratified in three age categories, i.e. 86 gilts, 87 primiparous and 89 pluriparous sows. Animals with clinical disease and/or reproductive disorders, such as puerperal disease or pathological vaginal discharge were not included.

Estrus stimulation started on the first day post weaning (pw) in sows or $48 \mathrm{~h}$ after the last altrenogest treatment in gilts (for the sake of convenience and consistency, the day of the last altrenogest treatment is henceforth referred to as the first day post-weaning or 'pw'), using at least two teaser boars. All animals were fed ad libitum with a gestation feed from day one pw until insemination. A supplement of $150 \mathrm{mg}$ dextrose

Table 1 Characteristics of the three pig herds included in the study

\begin{tabular}{|c|c|c|c|}
\hline & Herd A & Herd B & Herd C \\
\hline Number of sows per herd & 1200 & 1700 & 600 \\
\hline $\begin{array}{l}\text { Number of sows included } \\
\text { in study }\end{array}$ & 56 & 87 & 119 \\
\hline Breed of sows & Danbred $x$ York & $\mathrm{PIC}$ & Topigs20 \\
\hline $\begin{array}{l}\text { Batch-production-system } \\
\text { for sows (weeks) }\end{array}$ & 1 & 2 & 4 \\
\hline Lactation period (weeks) & 3 & 3 & 3 \\
\hline Piglets weaned/sow/year & 25.9 & 26.1 & 26.3 \\
\hline $\begin{array}{l}\text { Age of gilts at first insemination } \\
\text { (days) }\end{array}$ & 280 & 290 & 250 \\
\hline
\end{tabular}

per day per animal was provided as a top dressing. To further optimize estrus stimulation and detection, supplemental boar noises were played to the animals in herd A via a voice recorder, and herd $\mathrm{C}$ used a Contact-OMax (Ro-Main Europe, France), which is a remote controlled mobile unit with a boar inside.

Estrus detection was performed twice a day (am and $\mathrm{pm}$ ) from day four pw onwards. The same artificial insemination (AI) schedule was used in all three herds. Briefly, sows showing standing estrus on day $4 \mathrm{pw}$ in the morning were inseminated $24 \mathrm{~h}$ later, and those showing estrus in the evening were inseminated $12 \mathrm{~h}$ later. Sows showing standing estrus on day five were inseminated $8 \mathrm{~h}$ later, while those showing estrus on day 6 pw were inseminated immediately. Sows that still showed estrus $12 \mathrm{~h}$ after their first round of AI were inseminated a second time, and a third time in the rare cases where standing estrus persisted for $24 \mathrm{~h}$. Single sire semen from boars of proven fertility was purchased from a commercial AI centre.

Pregnancy testing was performed by the herd veterinarian using trans-abdominal ultrasound scans performed with a sectorial probe at 23 to 28 days after insemination and again two weeks later. Gilts and sows that were found to be pregnant at day 23 to 28 were moved to the gestation unit. In herds $\mathrm{A}$ and $\mathrm{B}$, pregnant females were housed in groups, with the exception of gilts and sows that had previously experienced reproductive problems (e.g. repeat breeding) in herd A. In herd C, only pregnant gilts were housed in groups, and pregnant sows were housed in individual stalls as was still in accordance with EU legislation in 2010. In all three herds, animals were fed $a d$ lib a gestation diet after confirmed pregnancy. Sows were moved to the farrowing unit approximately one week before the expected farrowing date.

To obtain equal litter sizes (12-13 piglets/litter), cross fostering of piglets was allowed within $24 \mathrm{~h}$ after farrowing, but only among sows of the same treatment group and after first weighing ( $<12 \mathrm{~h}$ after birth). Therefore, piglets were individually identified at first weighing using ear tags with different colors according to the treatment. Piglets in all three herds were weaned after twenty to twenty-two days of lactation.

\section{Experimental design}

Within each herd and each age category, animals were randomly allocated to one of three treatment groups prior to treatment (Tables 2, 3 and 4): 1) peforelin (the $\mathrm{P}$ group), in which gilts and pluriparous sows were treated with $150 \mu \mathrm{g}$ peforelin $(2 \mathrm{ml}$ Maprelin', Veyx-Pharma, Schwarzenborn, Germany) based on the manufacturers' instruction, and primiparous sows with $37.5 \mu \mathrm{g}$ peforelin $(0.5 \mathrm{ml}$ Maprelin ${ }^{\circ}$ [20]; 2) equine Chorion Gonadotropin (eCG; the E group) as a positive control, in which animals were 
Table 2 Mean back fat levels at the different time points in the different parity and treatment groups (with $P=$ peforelin, $E=e C G, C=$ control and BF1 = back fat measured one month after insemination; BF2 = back fat measured at farrowing; BF3 = back fat measured at weaning; $\mathrm{BF3}-\mathrm{BF} 2$ = calculated back fat loss during lactation and SD = standard deviation) in 212 sows in three herds

\begin{tabular}{lllcccc}
\hline & Group & $\mathrm{n}$ & $\mathrm{BF}_{1} \pm \mathrm{SD}(\mathrm{mm})$ & $\mathrm{BF}_{2} \pm \mathrm{SD}(\mathrm{mm})$ & $\mathrm{BF}_{3} \pm \mathrm{SD}(\mathrm{mm})$ & $\mathrm{BF}_{3}-\mathrm{BF}_{2} \pm \mathrm{SD}_{(\mathrm{mm})}$ \\
\hline Gilts & $\mathrm{P}$ & 28 & $16.5 \pm 3.5$ & $21.0 \pm 4.2$ & $17.5 \pm 4.2$ & $-3.3 \pm 2.6$ \\
& $\mathrm{E}$ & 17 & $17.7 \pm 2.1$ & $22.9 \pm 3.5$ & $18.9 \pm 2.8$ & $-3.6 \pm 3.2$ \\
Primiparous & $\mathrm{C}$ & 25 & $17.9 \pm 2.5$ & $22.3 \pm 3.8$ & $19.1 \pm 3.7$ & $-3.4 \pm 3.4$ \\
& $\mathrm{P}$ & 30 & $19.0 \pm 3.3$ & $21.9 \pm 5.6$ & $18.6 \pm 4.5$ & $-4.6 \pm 3.3$ \\
& $\mathrm{E}$ & 15 & $16.5 \pm 3.4$ & $20.7 \pm 3.1$ & $16.5 \pm 3.9$ & $-4.2 \pm 2.1$ \\
Pluriparous & $\mathrm{C}$ & 24 & $17.6 \pm 3.4$ & $20.6 \pm 3.3$ & $16.7 \pm 3.4$ & $-3.4 \pm 3.3$ \\
& $\mathrm{P}$ & 20 & $16.2 \pm 4.1^{\mathrm{b}}$ & $21.2 \pm 6.1$ & $16.4 \pm 3.2$ & $-4.0 \pm 2.9$ \\
All parities & $\mathrm{E}$ & 27 & $19.7 \pm 4.6^{\mathrm{a}}$ & $24.1 \pm 4.7$ & $19.1 \pm 4.5$ & $-3.3 \pm 4.2$ \\
& $\mathrm{C}$ & 26 & $17.8 \pm 3.8^{\mathrm{a}, \mathrm{b}}$ & $21.0 \pm 4.2$ & $17.8 \pm 3.6$ & $-4.3 \pm 3.6$ \\
& $\mathrm{P}$ & 78 & $18.4 \pm 3.6$ & $22.2 \pm 4.5$ & $18.1 \pm 4.0$ & $-4.0 \pm 3.0$ \\
& $\mathrm{E}$ & 59 & $17.5 \pm 3.5$ & $21.8 \pm 4.3$ & $18.3 \pm 4.0$ & $-3.4 \pm 3.7$ \\
\hline
\end{tabular}

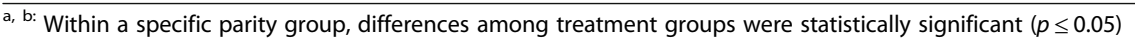

treated with 1000 IU eCG (1 ml Folligon ${ }^{\circ}$, MSD Animal Health, Brussels, Belgium) and 3) physiological saline solution as a negative control (the $\mathrm{C}$ group), in which animals were treated with $1 \mathrm{ml}$ of $0.9 \% \mathrm{NaCl}$ sterile solution (Baxter, Lessen, Belgium). All treatments were applied via intramuscular injection into the neck $24( \pm 1) \mathrm{h}$ post weaning (sows) or $48( \pm 1) \mathrm{h}$ after the last altrenogest administration (gilts). The entire study, including AI and the recording of the different parameters, as described below, was conducted using a blinded design.

Table 3 Number of total born (TB), live born (LB) and stillborn (SB) piglets according to treatment $(P=$ peforelin, $E=e C G$, $\mathrm{C}=$ control) and parity of 212 litters of three herds

\begin{tabular}{llllll}
\hline & Group & $n$ & \multicolumn{3}{l}{ Litter numbers (mean \pm standard deviation) } \\
\cline { 3 - 6 } & & & TB & LB & \multicolumn{2}{l}{ SB } \\
\hline Gilts & P & 28 & $13.1 \pm 3.4$ & $12.3 \pm 2.9$ & $0.7 \pm 0.9$ \\
& E & 17 & $15.2 \pm 2.8$ & $13.5 \pm 3.1$ & $1.6 \pm 2.7$ \\
Primiparous & C & 25 & $14.2 \pm 3.5$ & $13.6 \pm 3.4$ & $0.6 \pm 1.0$ \\
& P & 30 & $14.8 \pm 3.9$ & $13.6 \pm 3.4$ & $1.0 \pm 1.8$ \\
& E & 15 & $15.7 \pm 3.2$ & $14.4 \pm 2.9$ & $1.3 \pm 1.5$ \\
Pluriparous & C & 24 & $14.0 \pm 3.0$ & $13.3 \pm 3.1$ & $0.5 \pm 0.9$ \\
& P & 20 & $15.1 \pm 3.7$ & $12.4 \pm 3.8$ & $2.2^{\mathrm{a}} \pm 0.5$ \\
& E & 27 & $14.9 \pm 4.4$ & $13.7 \pm 3.8$ & $0.9^{\mathrm{b}} \pm 1.0$ \\
& $\mathrm{C}$ & 26 & $14.4 \pm 4.4$ & $12.9 \pm 4.2$ & $1.4^{\mathrm{a}, \mathrm{b}} \pm 2.3$ \\
& $\mathrm{P}$ & 78 & $14.3 \pm 3.7$ & $12.8 \pm 3.3$ & $1.3 \pm 1.8$ \\
& $\mathrm{E}$ & 59 & $15.2 \pm 3.7$ & $13.8 \pm 3.4$ & $1.2 \pm 1.8$ \\
& $\mathrm{C}$ & 75 & $14.2 \pm 3.6$ & $13.2 \pm 3.6$ & $0.9 \pm 1.6$ \\
\hline
\end{tabular}

$\mathrm{a}, \mathrm{b}$ Within a specific parity group, differences among treatment groups were statistically significant $(p \leq 0.05)$

\section{Data recording and calculated measures}

From each litter, the number of total born, live born, stillborn and mummified piglets was noted. All piglets (live and stillborn) were individually identified and weighed within $12 \mathrm{~h}$ after birth, but before cross fostering. The coefficient of variation was calculated as the standard deviation divided by the mean, to assess the

Table 4 Mean birth weight \pm standard deviation $(B W \pm S D$, in $\mathrm{kg}$ ) and coefficient of variation (CV) based on the sum of live born and stillborn piglets $(\mathrm{LB}+\mathrm{SB})$ and based on $\mathrm{LB}$ piglets only, and mortality rate (MR) according to treatment ( $P=$ peforelin, $E=e C G, C=$ control) and parity of 3014 piglets (2688 LB) in 212 litters in three herds

\begin{tabular}{|c|c|c|c|c|c|c|c|}
\hline \multirow[t]{3}{*}{ Parity } & \multirow[t]{3}{*}{ Group } & \multirow[t]{3}{*}{$n$} & \multicolumn{4}{|l|}{ Weight } & \multirow{3}{*}{$\begin{array}{l}\text { MR } \\
\text { (\%) }\end{array}$} \\
\hline & & & \multicolumn{2}{|l|}{$B W_{-} L B+S B$} & \multicolumn{2}{|l|}{ BW_LB } & \\
\hline & & & Mean \pm SD & $\mathrm{CV}$ & Mean \pm SD & $\mathrm{CV}$ & \\
\hline \multirow[t]{3}{*}{ Gilts } & $P$ & 28 & $1.33^{a} \pm 0.37$ & 0.19 & $1.36^{a} \pm 0.34$ & 0.22 & 9 \\
\hline & E & 17 & $1.23^{b} \pm 0.31$ & 0.22 & $1.26^{b} \pm 0.30$ & 0.22 & 13 \\
\hline & C & 25 & $1.29^{a, b} \pm 0.34$ & 0.21 & $1.32^{\mathrm{a}, \mathrm{b}} \pm 0.32$ & 0.21 & 12 \\
\hline \multirow[t]{3}{*}{ Primiparous } & $P$ & 30 & $1.42 \pm 0.41$ & 0.25 & $1.47 \pm 0.39$ & 0.22 & 12 \\
\hline & E & 15 & $1.37 \pm 0.36$ & 0.27 & $1.40 \pm 0.35$ & 0.25 & 13 \\
\hline & C & 24 & $1.42 \pm 0.40$ & 0.25 & $1.45 \pm 0.37$ & 0.23 & 12 \\
\hline \multirow[t]{3}{*}{ Pluriparous } & $P$ & 20 & $1.36 \pm 0.43$ & 0.25 & $1.41 \pm 0.40$ & 0.26 & 15 \\
\hline & $\mathrm{E}$ & 27 & $1.34 \pm 0.39$ & 0.26 & $1.38 \pm 0.36$ & 0.23 & 16 \\
\hline & C & 26 & $1.38 \pm 0.48$ & 0.25 & $1.43 \pm 0.46$ & 0.23 & 12 \\
\hline \multirow[t]{3}{*}{ All parities } & $P$ & 78 & $1.37^{\mathrm{a}} \pm 0.40$ & 0.22 & $1.42^{\mathrm{a}} \pm 0.38$ & 0.23 & 12 \\
\hline & E & 59 & $1.31^{b} \pm 0.36$ & 0.25 & $1.35^{\mathrm{b}} \pm 0.35$ & 0.23 & 14 \\
\hline & C & 75 & $1.36^{\mathrm{a}} \pm 0.41$ & 0.23 & $1.40^{\mathrm{a}} \pm 0.39$ & 0.22 & 12 \\
\hline
\end{tabular}

$\mathrm{a}, \mathrm{b}$ Within a specific parity group, differences among treatment groups were statistically significant $(p \leq 0.05)$ 
weight variations within a litter. Mortality rate was used to describe pre-weaning mortality.

Back fat levels of gilts and sows were measured one month after AI following treatment (BF1), the day of farrowing (BF2) and of weaning (BF3). The measurements were performed at the P2 position [21] by one operator using ultrasonography (linear probe, Tringa, Pie Medical ESAOTE, Belgium, The Netherlands and Luxemburg). Differences among BF3 and BF2 were calculated in order to determine the losses in back fat during lactation.

\section{Statistical analysis}

Of the initial 262 animals, sixteen gilts and thirty-four sows were not pregnant or had incomplete records and were excluded from the analysis. Results for a total of 212 animals were included in the statistical analysis: 70 gilts, 69 primi- and 73 pluriparous sows. Statistical analysis was performed using version 20.0 of the SPSS software package (SPSS Inc., Chicago, Illinois, USA). Normal distribution of the data was tested using the Kolmogorov-Smirnov-test and the Shapiro-Wilk-test. The results for the different treatment groups were expressed as arithmetic means and the corresponding standard deviations (SD). For each outcome of interest a linear model was fitted (General Linear Model procedure in SPSS) and results were compared among treatment groups and among treatment groups and age categories by using the post hoc Scheffé test to adjust the $p$-values for the multiple comparisons. The analyses for outcome variables at the sow level (litter numbers and mortality rate) were adjusted for back fat levels whenever back fat was significantly associated with the outcome $(p<0.05)$. Furthermore, herd was included in the analyses as random effect to account for clustering of piglets and sows within herds. A significance level of $p \leq 0.05$ was employed.

\section{Results}

The only significant difference for back fat measurements was found in the pluriparous sows one month after insemination (BF1), with the sows in the P group having the lowest back fat $(16.2 \pm 4.1 \mathrm{~mm})$ compared to the sows in the E group $(19.7 \pm 4.6 \mathrm{~mm}, p=0.01)$. No significant differences were found among any of the treatments for the other parity groups at any time for the back fat measurements, nor for the calculated back fat losses during lactation (Table 2).

Table 3 shows the numbers of total born, live born and stillborn piglets according to parity and treatment. Litter size was numerically greater in the E group in all parity groups except for the pluriparous sows. Only the number of stillborn piglets in pluriparous sows was significantly higher in the $\mathrm{P}$ group, compared to the $\mathrm{E}$ group $(p=0.04)$, but not compared to the $\mathrm{C}$ group $(p>0.05)$. The number of mummified piglets per litter over all parities was similar for all treatment groups: $0.2 \pm 0.6,0.2 \pm 0.5$ and $0.1 \pm 0.4$ mummies for the P, E and $C$ group respectively $(p>0.05)$.

In total, 3014 piglets (2688 live born) were individually weighed at birth (Table 4). The average birth weight both with and without stillborn numbers, was significantly higher in the $\mathrm{P}$ group, compared to the $\mathrm{E}$ group $(p \leq 0.02)$, and numerically higher, compared to the C group in gilts. On average a higher birth weight was observed in the $\mathrm{P}$ and $\mathrm{C}$ group compared to the $\mathrm{E}$ group over all parity groups both for total born piglets and for live born piglets alone $(p<0.01$; Table 4$)$.

No significant differences among any of the treatments for each parity group were found with respect to mortality rate during lactation (Table 4).

\section{Discussion}

This study investigated the effects of peforelin, i.e. synthetic l-GnRH-III, on the litter performance of gilts after altrenogest treatment and of post-weaning sows in commercial Belgian pig herds, compared to treatment with eCG and no treatment. As this study was part of a larger trial, of which the main objective was to demonstrate differences in estrus rate between the treatment groups [17], statistical sample size calculations were performed in relation to this main objective. Therefore the power of the statistical analysis in the current study is often quite low, possibly resulting in non-significant differences. However, even with low power some significant differences could yet be demonstrated.

No significant differences were observed among the negative control group and the group treated with peforelin considering litter size and mortality rate. The birth weights of the piglets in the eCG group were lower in all parity groups and in gilts.

Although, litter size was numerically higher in gilts treated with eCG, compared to no treatment or peforelin treatment. The effect of treatment with supplemental LH-like activity products (such as eCG) was shown to be age dependent [22]. Therefore it is possible that the endogenous LH support of older sows is adequate enough to support follicular development, whereas that of gilts is maybe insufficient. Treatment with eCG in gilts and younger sows could thus have more influence on the outcome of total born piglets, compared to the litter size in older sows. The lack of significant differences with respect to litter size among the control and treatment groups in sows is consistent with the results of earlier studies [22, 23]. do Lago et al. (2005) and Martinat-Botté et al. (2010) found that eCG treatment increased the ovulation rate $[2,24]$, leading to larger litter sizes. This was the case for the eCG treated group in gilts in this 
study. Hence, the lower birth weights in this treatment group over all parity groups was possibly caused by the differences in total and live born piglets, as piglets born in a large litter mostly have lower birth weights, compared to piglets in small litters [25-28].

Several environmental factors, e.g. ventilation, nutrition, farrowing supervision may influence the stillbirth rate [29]. The overall management practices around farrowing were similar for all treatment groups within each of the three herds, therefore the higher stillborn number in the P group of the pluriparous sows was probably not caused by environmental factors. A lower birth weight was found to increase the probability of stillbirth [30] and, vice versa, a higher birth weight $(>1.35 \mathrm{~kg}$ [31]) could lead to more birth difficulties, due to the relatively large size compared to the maternal pelvis, leading to asphyxia and likely to more stillborn piglets [32]. Although the birth weight of the stillborn piglets was significantly higher in the $\mathrm{P}$ group of the pluriparous sows, compared to the E group (data not shown), it did not exceed $1.35 \mathrm{~kg}$, thus a higher number of stillborns due to difficulties during farrowing is doubtful. Sow factors, such as body condition and farrowing duration have also been shown to influence the number of stillborn piglets [29]. The back fat of the pluriparous sows at farrowing was similar for the $\mathrm{P}$ and $\mathrm{C}$ group and was approximately $20 \mathrm{~mm}$, which would not have detrimental effects on the number of stillborns [21]. The farrowing duration was not measured in this trial, therefore no conclusion can be drawn on a possible influence of this parameter.

Previous studies have shown that l-GnRH-III treatment could increase FSH levels [13, 33-35]. Increased levels of FSH during the follicular phase increase follicular size $[4,36]$. It was hypothesized that treatment with peforelin results in a more uniform pre-ovulatory pool, containing more competent and larger follicles to ovulate [20]. A more uniform pre-ovulatory follicle pool may result in a more uniform oocyte quality [37] and more uniformly developed embryos [38, 39], which could finally result in more uniform birth weights $[8,18,19]$. It has been shown that animals treated with peforelin, similar as in the present study, had larger preovulatory follicles than control and eCG treated animals [17, 20]. The coefficient of variation of birth weights is a measure of the homogeneity of the piglets' weight at birth. A low withinlitter-variation in birth weight is beneficial, as this is positively associated with survival and performance of the piglets $[40,41]$. However, no significant differences were found in the coefficient of variation in none of the parity groups in this study.

\section{Conclusion}

In conclusion, peforelin treatment showed no difference compared to no treatment based on litter performance.
On the opposite, litter size seems to be numerically higher in gilts, treated to eCG, compared to control of peforelin treated groups, however, the differences between groups were not statistically significant. A possible consequence of the higher litter size, is the lower birth weight of the piglets.

\section{Abbreviations}

Al: Artifical Insemination; BF: Back Fat; BW: Birth weight; eCG: Equine Chorion Gonadotropin; FSH: Follicle stimulating hormone; GnRH: Gonadotropin Releasing Hormone; LB: Live born; I-GnRH-III: Lamprey - Gonadotropin Releasing Hormone - III; LH: Luteinizing hormone; MR: Mortality rate; pw: post weaning; SB: Still born; SD: Standard deviation; TB: Total born

\section{Acknowledgements}

The authors thank the pig farmers for their willingness to participate in this study.

\section{Funding}

Veyx-Pharma and Elanco Animal Health are acknowledged for the financial support of the study.

\section{Availability of data and materials}

The datasets used and/or analysed during the current study are available from the corresponding author on reasonable request.

\section{Authors' contributions}

EJ has contributed to the design of the study, the practical work, the statistical analysis and the draft of the paper. Dr. JJ has contributed to the design of the study, the statistical analysis and the draft of the paper. Prof. Dr. JK has contributed to the design of the study and the draft of the paper. Prof. Dr. JD and Dr. SS has contributed to the statistical analysis. Prof. Dr. DM has contributed to the design of the study and the draft of the paper. All authors read and approved the final manuscript.

\section{Competing interests}

The authors declare that they have no competing interests.

\section{Consent for publication}

Not applicable.

\section{Ethics approval}

The study was approved by the Ethical Committee of the Faculty of Veterinary Medicine of Ghent University (approval: EC2010/035). All farmers were personally contacted and participated on a voluntary base.

\section{Author details}

${ }^{1}$ Department of Reproduction Obstetrics and Herd Health, Unit Porcine Health Management, Faculty of Veterinary Medicine, University of Ghent, Salisburylaan 133, B-9820 Merelbeke, Belgium. Elanco, S.A. Eli Lilly Benelux N.V., Stoofstraat 52, B-1000 Brussels, Belgium. ${ }^{3}$ Large Animal Clinic for Theriogenology and Ambulatory Services, Faculty of Veterinary Medicine, University of Leipzig, An den Tierkliniken 19, 04103 Leipzig, Germany. ${ }^{4}$ Department of Reproduction Obstetrics and Herd Health, Veterinary Epidemiology Unit, Faculty of Veterinary Medicine, University of Ghent, Salisburylaan 133, B-9820 Merelbeke, Belgium. ${ }^{5}$ Present address: Flemish Animal Health Service (Dierengezondheidszorg Vlaanderen), Industrielaan 29, B-8820 Torhout, Belgium.

Received: 26 April 2016 Accepted: 10 February 2017

Published online: 15 March 2017

\section{References}

1. Brüssow KP, Schneider F, Tuchscherer A, Kanitz W. Influence of synthetic lamprey $\mathrm{GnRH}$-III on gonadotropin release and steroid hormone levels in gilts. Theriogenology. 2010;74(9):1570-8.

2. Martinat-Botté $F$, Venturi $E$, Guillouet $P$, Driancourt MA, Terqui M. Induction and synchronization of ovulations of nulliparous and multiparous sows with an injection of gonadotropin-releasing hormone agonist (Receptal). Theriogenology. 2010;73:332-42. 
3. Benaglia P, Krejci R, Lopez A, Casappa P. Effect of the synchronisation of estrus in sows using Fertipig ${ }^{\circledast}$ in comparison with another gonadotropin product. Jeju: Proceedings 22nd IPVS; 2012. p. 92.

4. Knox RV. Recruitment and selection of ovarian follicles for determination of ovulation rate in the pig. Dom Anim Endocrin. 2005;29:385-97.

5. Ferguson EM, Slevin J, Edwards SA, Hunter MG, Ashworth CJ. Effect of alterations in the quantity and composition of the pre-mating diet on embryo survival and foetal growth in the pig. Anim Reprod Sci. 2006;96:89-103.

6. Ferguson EM, Slevin J, Hunter MG, Edwards SA, Ashworth CJ. Beneficial effects of a high fibre diet on oocyte maturity and embryo survival in gilts. Reproduction. 2007;133:433-9.

7. Ferguson EM, Ashworth CJ, Hunter MG, Penny P, Slevin J, Edwards SA. The effect of feeding a high fibre diet from mid lactation until breeding on subsequent litter size of sows. In: Thompson JE, Gill BP, Varley MA, editors. The appliance of pig science. Nottingham: Nottingham University Press; 2004. p. 175-9.

8. Wientjes JGM, Soede NM, Van den Brand H, Kemp B. Nutritionally induced relationships between insulin levels during the weaning-to-ovulation interval and reproductive characteristics in multiparous sows: II. Luteal development, progesterone and conceptus development and uniformity. Reprod Dom Anim. 2012:47:62-8.

9. Brüssow KP, Schneider F, Nürnberg G. Alteration of gonadotrophin and steroid hormone release and of ovarian function by a $\mathrm{GnRH}$ antagonist in gilts. Anim Reprod Sci. 2001;66:117-28.

10. McCann SM, Marubayashi U, Sun H-Q, Yu WH. Control of follicle-stimulating hormone and luteinizing hormone release by hypothalamic peptides. Ann N Y Acad Sci. 1993;687:55-9.

11. McCann SM, Karanth S, Mastronardi CA, Dees WL, Childs G, Miller B, Sower S, Yu WH. Control of Gonadotropin secretion by Follicle-Stimulating Hormone-Releasing Factor, Luteinizing Hormone-Releasing Hormone and Leptin. Arch Med Res. 2001;32:476-85.

12. Padmanabhan $\mathrm{V}$, McNeilly AS. Is there an FSH-releasing factor? Reproduction. 2001;121:21-30.

13. Kauffold J, Schneider F, Zaremba W, Brüssow KP. Lamprey GnRH-III stimulates FSH secretion in barrows. Reprod Dom Anim. 2005;40:475-9.

14. Sower SA, Chiang Y, Lovas S, Conlon JM. Primary structure and biological activity of a third gonadotropin-releasing hormone from lamprey brain. Endocrinology. 1993;60:1125-31.

15. Engl S, Zepperitz H, Rath R, Zaremba W. Practical experience with Peforelin in a large sow herd: data from primiparous sows. Vancouver: Proceedings 21st IPVS; 2010. p. 1085.

16. Engl S, Zepperitz H, Rath R, Zaremba W. Practical experience with Peforelin in a large sow herd: data from pluriparous sows. Vancouver: Proceedings 21st IPVS; 2010. p. 1086.

17. de Jong E, Kauffold J, Engl S, Jourquin J, Maes D. Effect of a GnRH analogue (Maprelin ${ }^{\odot}$ ) on the reproductive performance of gilts and sows. Theriogenology. 2013;80:870-7

18. Jourquin J, Goossens L. Impact of oestrus induction with Peforelin on subsequent litter performance. Belek, Antalya: Proceedings 15th ESDAR; 2011. p. 129

19. Vangroenweghe $F$, Van Loocke $H$, Labarque $G$, Jouquin J. Effect of a GnRH analogue (peforelin) on subsequent reproductive performance and piglet birth weight on a high productive farm. Edinburgh: Proceedings 5th ESPHM; 2013. p. 204.

20. Engl S. Untersuchungen zur Eignung einer neuen GnRH-Variante zur Brunstinduktion bei pluripare Sauen. Leipzig: Inaugural-Dissertation zur Erlangung des Grades eines Doctor medicinae veterinariae; 2006.

21. Maes D, Janssens G, Delputte P, Lammertyn A, de Kruif A. Back fat measurements in sows from three commercial pig herds: relationship with reproductive efficiency and correlation with visual body condition scores. Livest Prod Sci. 2004:91:57-67.

22. Manjarin R, Garcia JC, Dominguez JC, Castro MJ, Alegre B, Munoz JD, Kirkwood RN. Effect of gonadotropin treatment on estus, ovulation and litter size in weaned and anestrus sows. J Anim Sci. 2010;7:2356-60.

23. Patterson JL, Cameron AC, Smith TA, Kummer AB, Schott RL, Greiner LL, Connor JF, Foxcroft GR. The effect of gonadotrophin treatment at weaning on primiparous sow performance. J Swine Health Prod. 2010;18(4):196-9.

24. do Lago V, Vianna WL, Gama RD, de Campos Rosseto A, Pinese ME, de Sant'Anna Moretti A. Second oestrus synchronization and precocious embryo viability after puberty induction in gilts by the use of Gonadotrophin treatment. Reprod Dom Anim. 2005:40:141-4.
25. Kerr JC, Cameron ND. Reproductive performance of pigs selected for components of efficient lean growth. Anim Sci. 1995;60(2):281-90.

26. Roehe R. Genetic determination of individual birth weight and its association with sow productivity traits using Bayesian analyses. J Anim Sci. 1999;77(2):330-43.

27. Sorensen D, Vernersen A, Andersen S. Bayesian analysis of response to selection: a case study using litter size in Danish Yorkshire pigs. Genetics. 2000;156(1):283-95.

28. Beaulieu AD, Aalhus JL, Williams NH, Patience JF. Impact of piglet birth weight, birth order, and litter size on subsequent growth performance, carcass quality, muscle composition, and eating quality of pork. J Anim Sci. 2010;88(8):2767-78.

29. Vanderhaeghe C, Dewulf J, de Kruif A, Maes D. Non-infectious factors associated with stillbirth in pigs: a review. Anim Reprod Sci. 2013;139(1-4):76-88.

30. Canario L, Cantoni E, Le Bihan E, Caritez JC, Billon Y, Bidanel JD, Foulley JL. Between-breed variability of stillbirth and its relationship with sow and piglet characteristics. J Anim Sci. 2006;84(12):3185-96.

31. Knol EF, Leenhouwers JL, Van der Lende T. Genetic aspects of piglet survival. Livest Prod Sci. 2002;78:47-55.

32. Olmos-Hernández A, Alonso-Spilsbury M, Nava-Ocampo A, Truijillo Ortega ME, Orozco-Gregorio H, Ramírez-Necoechea R, Mota-Rojas D. Heavier newborn piglets are more prone to intra-partum asphyxia and show longer first udder contact vs. average weight pigs. Durban: Proceedings 20th IPVS; 2008. p. 223.

33. Yu WH, Karanth S, Walczewska A, Sower SA, McCann SM. A hypothalamic follicle-stimulating hormone-releasing decapeptide in the rat. Proceedings National Academy Science USA. 1997;94:9449-503.

34. Yu WH, Karanth S, Sower SA, Parlow AF, McCann SM. The similarity of FSHreleasing factor to lamprey gonadotropin-releasing hormone III (I-GnRH-III). Proceedings Society for Experimental Biology and Medicine. 2000;224:87-92.

35. Dees WL, Dearth RK, Hooper RN, Brinsko SP, Romano JE, Rahe H, Yu WH, McCann SM. Lamprey gonadotropin-releasing hormone-III selectively releases follicle-stimulating hormone in the bovine. Dom Anim Endocrin. 2001;20:279-88

36. Picton HM, Miller AT, Hunter MG. Effect of FSH infusion on follicle development in GnRH agonist-treated gilts. J Reprod Fert. 1999;117(2):246-57.

37. Zak $L$, Xu X, Hardin RT, Foxcroft GR. Impact of different patterns of feed intake during lactation in the primiparous sow on follicular development and oocyte maturation. J Reprod Fert. 1997;110:99-110.

38. Pope WF, Xie S, Broermann DM, Nephew KP. Causes and consequences of early embryonic diversity in pigs. J Reprod Fert Suppl. 1990;40:251-60.

39. Xie S, Broermann DM, Nephew KP, Geisert RD, Pope WF. Ovulation and early embryogenesis in swine. Biol Reprod. 1990;43:236-40.

40. Damgaard LH, Rydhmer L, Lovendahl P, Grandinson K. Genetic parameters for within-litter variation in piglet birth weight and change in within-litter variation during suckling. J Anim Sci. 2003;81:604-10.

41. Milligan BN, Dewey CE, de Grau AF. Neonatal-piglet weight variation and its relation to pre-weaning mortality and weight gain on commercial farms. Prev Vet Med. 2002;56(2):119-27.

\section{Submit your next manuscript to BioMed Central and we will help you at every step:}

- We accept pre-submission inquiries

- Our selector tool helps you to find the most relevant journal

- We provide round the clock customer support

- Convenient online submission

- Thorough peer review

- Inclusion in PubMed and all major indexing services

- Maximum visibility for your research

Submit your manuscript at www.biomedcentral.com/submit 